\title{
DEGRADATION OF HUMAN IMMUNOGLOBULINS G AND M AND COMPLEMENT FACTORS C3 AND C5 BY BLACK-PIGMENTED BACTEROIDES
}

\author{
G. Sundqvist, J. Carlsson*, B. Herrmann and A. Tärnvik $\dagger$ \\ Departments of Endodontics, * Oral Microbiology and $†$ Clinical Microbiology, Univer- \\ sity of Umeå, S-901 87 Umeå, Sweden
}

\begin{abstract}
Summary. Strains of Bacteroides, Capnocytophaga and Fusobacterium were examined by immunological methods for their ability to degrade the human serum proteins IgG, IgM, C3 and C5. The proteolytic activity of the strains was measured in terms of the breakdown of serum into trichloroacetic acid-soluble material. Only black-pigmented $\mathrm{Bac}$ teroides strains showed proteolytic activity. Strains of $B$. gingivalis degraded IgG, IgM, C3 and C5, strains of B. intermedius IgG and C3, strains of $B$. endodontalis $\mathrm{C} 3$ and $\mathrm{IgG}$ and a strain of $B$. loeschei degraded only IgG. These findings are discussed in relation to the pathogenicity of the black-pigmented Bacteroides.
\end{abstract}

\section{INTRODUCTION}

Some clinically important bacteria produce enzymes that are able to cleave plasma proteins involved in the host defence against microbial infections. Immunoglobulin A (IgA) proteases are produced by Neisseria gonorrhoea, N. meningitidis, Haemophilus influenzae and Streptococcus pneumoniae. These bacteria colonise the IgA-coated mucous membranes and are all pathogenic to man (Plaut et al., 1975; Kilian, Mestecky and Schrohenloher, 1979; Male, 1979). IgA is also degraded by strains of Bacteroides gingivalis, B. intermedius and B. melaninogenicus (Werner and Müller, 1971; Kilian, 1981) which are suspected to be pathogens in periodontal disease. They have also been isolated from abscesses adjacent to the oral cavity. Some of these Bacteroides strains may also produce IgG-cleaving enzymes (Werner and Müller, 1971; Kilian, 1981).

Bacteria may release substances which cause consumption of serum complement. Pseudomonas aeruginosa, Serratia marcescens and $\beta$-haemolytic streptococci all produce proteinases that are able to cleave human serum complement components $C 3$ and C5 (Ward et al., 1973; Schultz and Miller, 1974). We have recently reported that C3 is extensively degraded by $B$. gingivalis in vitro and in experimentally infected guinea pigs (Sundqvist et al., 1984).

In the present study, the ability of strains of the genera Bacteroides, Fusobacterium and Capnocytophaga to degrade IgG, IgM, C3 and C5 in human serum was assayed. Special precautions were taken to exclude the possibility that $\mathrm{C} 3$ was eliminated by activation of serum complement by the bacteria. 


\section{MATERIAL AND METHODS}

Bacterial strains and culture conditions. The strains tested are listed in table I. Reference strains were obtained from the American Type Culture Collection (ATCC), Rockville, MD; the National Collection of Type Cultures (NCTC), Colindale, UK; Virginia Polytechnic Institute (VPI), Blacksburg, VI; and the National Collection of Diary Organisms (NCDO), Reading, UK. B. asaccharolyticus strain B537 and B. gingivalis strains W83, W50, 381, 376 were obtained from T.J.M. van Steenbergen, Department of Oral Microbiology, Vrije Universiteit, Amsterdam, The Netherlands. Other strains were isolated by the authors from dental root canals. All the strains were stored on blood agar in an anaerobic box with an atmosphere of $\mathrm{CO}_{2} 5 \%, \mathrm{H}_{2} 10 \%$ and $\mathrm{N}_{2}$ $85 \%$. The blood-agar medium contained defibrinated horse blood haemolysed by freezing and thawing (Holdeman, Cato and Moore, 1977). To suspend bacteria a previously described medium (Neidhardt, Bloch and Smith, 1974) was modified to contain $40 \mathrm{~mm} 3-\mathrm{N}$-morpholinopropane-sulphonic acid, $4 \mathrm{~mm}$ tricine (Sigma Chemical Co., St Louis, MO, USA), 0.3 mM potassium sulphate, $0.5 \mu \mathrm{M}$ calcium chloride, $0.5 \mathrm{~mm}$ magnesium chloride, and $50 \mathrm{~mm}$ sodium chloride. It was adjusted to $p \mathrm{H} 7.4$ with potassium hydroxide, sterilised by filtration and designated MOPS.

Assay of proteolytic activity. Bacteria harvested from blood-agar plates after incubation for 4 days were suspended in MOPS to a density of $c .10^{9} \mathrm{cfu}(0 \cdot 3 \mathrm{mg}$ dry weight $) / \mathrm{ml}$. The proteolytic activity of bacterial cells was assayed in anaerobic conditions in a reaction mixture containing $0.6 \mathrm{ml}$ of pooled serum from healthy adult donors and $0.3 \mathrm{ml}$ of bacterial suspension. After incubation at $37^{\circ} \mathrm{C}$ for $24 \mathrm{~h}, 0.1 \mathrm{ml}$ of the reaction mixture was precipitated in $0.4 \mathrm{ml}$ of ice-cold $0.25 \mathrm{M}$ trichloroacetic acid. After centrifugation, the extinction of the supernatant fluid was read at $280 \mathrm{~nm}$. The standard was $1 \mathrm{~mm}$ L-tyrosine in $0.25 \mathrm{M}$ trichloroacetic acid.

Analysis of serum proteins. Samples of the reaction mixtures were centrifuged to remove bacteria. They were assayed for IgG and IgM by radial immunodiffusion and for $\mathrm{C} 3$ and $\mathrm{C} 5$ by rocket immunoelectrophoresis (Laurell, 1972). Immunodiffusion was performed in a humidified chamber at $23^{\circ} \mathrm{C}$ for $24 \mathrm{~h}$. To samples to be analysed for C3 and C5, EDTA was added to a final concentration of $5 \mathrm{~mm}$ before electrophoresis. Samples $(5 \mu \mathrm{l})$ were applied to wells $(2.5 \mathrm{~mm})$ in

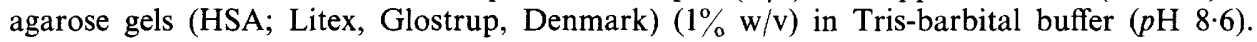
Electrophoresis was performed at $10 \mathrm{~V} / \mathrm{cm}$ for $4 \mathrm{~h}$ in the same buffer.

The electrophoretic homogeneity of $\mathrm{C} 3$ in the treated sera was studied by crossed immunoelectrophoresis (Ganrot, 1972). Samples $(5 \mu \mathrm{l})$ were electrophoresed at $4 \mathrm{~V} / \mathrm{cm}$ in agarose gel $1 \% \mathrm{w} / \mathrm{v}$ in Tris-barbital buffer $(\mathrm{pH} 8.6)$ until bromophenol blue-marked albumin had moved $40 \mathrm{~mm}$ in the gel. The second dimension run into the antibody-containing gel was performed at $2 \mathrm{~V} / \mathrm{cm}$ for $20 \mathrm{~h}$ in the same buffer. Antisera against IgG, IgM, C3c, C3d, C5 (Dakopatts A/S, Copenhagen, Denmark) and C3 ( $\beta 1 \mathrm{c} / \beta 1 \mathrm{~A})$ (Cappel Laboratories, Cochranville, PA, USA) were used.

After electrophoresis, agarose gels were washed with saline (sodium chloride $0.85 \% \mathrm{w} / \mathrm{v}$ ) to remove excess protein and were stained with Coomassie brilliant blue R-250, $0 \cdot 1 \% \mathrm{w} / \mathrm{v}$, (Serva Feinbiochemica, Heidelberg, West Germany) in ethanol $50 \%$ and acetic acid $10 \%$ in water. Gels were destained in ethanol $50 \%$ and acetic acid $10 \%$ in water.

Proteins of the bacteria-treated sera were also separated by polyacrylamide gradient gel electrophoresis (Pharmacia Fine Chemicals, Uppsala, Sweden). The gradient gel slabs contained 4-30\% polyacrylamide, and electrophoresis was run in a Tris buffer $(p \mathrm{H} 8.4)$, containing $90 \mathrm{~mm}$ Tris, $80 \mathrm{~mm}$ boric acid and $2.5 \mathrm{~mm}$ EDTA. The samples were prepared by mixing $25 \mu \mathrm{l}$ of the cell-free fluid, $10 \mu \mathrm{l}$ of a $40 \% \mathrm{w} / \mathrm{v}$ sucrose solution, and $0.5 \mu \mathrm{l}$ of a solution of bromophenol blue $1 \%$ in ethanol. A 3- $\mu 1$ sample of this mixture was applied to the gel and the electrophoresis was run at $4^{\circ} \mathrm{C}$ for $24 \mathrm{~h}$ at $120 \mathrm{~V}$. After the run the proteins were fixed and stained with Coomassie brilliant blue R-250.

Removal of complement component $C 4$ and Factor $B$ from serum. The effect of the bacteria was also assayed on sera depleted of $\mathrm{C} 4$ and Factor B. Affinity chromatography was used to remove these factors as described by Löfgren, Tärnvik and Carlsson (1980). The absorbed serum was assayed for IgG, IgM, IgA, C3, C4 and Factor B by radial immunodiffusion in Partigen plates (Behringwerke AG, Marburg, West Germany). There was no detectable C4 and Factor B in the depleted serum. The levels of $\mathrm{IgG}, \mathrm{IgM}, \mathrm{IgA}$ and $\mathrm{C} 3$ were not affected by the chromatography. 
There was no haemolytic activity by either the classical or alternative pathway in the C4- and Factor B-depleted serum.

Assay of complement activation. The activation of complement by the alternative pathway was determined by a technique based on haemolysis in gel of rabbit erythrocytes (Fong and Renaud, 1978) and the activation of complement by the classical pathway with antibody coated sheep erythrocytes (Lange, 1962).

\section{RESUlts}

Proteolytic activity of bacterial cells as measured by degradation of serum into trichloroacetic acid-soluble material within $24 \mathrm{~h}$ was demonstrated in four of the 29 tested species of the genera Bacteroides, Fusobacterium and Capnocytophaga. These were the black-pigmented Bacteroides: $B$. gingivalis, $B$. intermedius, $B$. asaccharolyticus and $B$. endodontalis (table). Of the 22 strains of these four species that were tested, only two strains of $B$. asaccharolyticus were not proteolytic. As demonstrated by polyacrylamide gradient gel electrophoresis, strains of $B$. gingivalis hydrolysed most of the serum proteins into fragments of mol.wt $<30 \times 10^{3}$ (fig. 1). Strains of $B$. intermedius also degraded many of the serum proteins. The following strains showed no proteolytic activity and no degradation of C3, C5, IgG or IgM: B. buccae ATCC33574, B. buccalis NCDO2354, B. coagulans ATCC29798, B. denticola NCDO2352, B. distasonis ATCC8503, B. fragilis NCTC9343 and NCTC10584, B. oralis ATCC33269, B. oris ATCC33573, B. ovatus ATCC8483, B. pentosaceus NCDO2353, B. ruminicola ss.

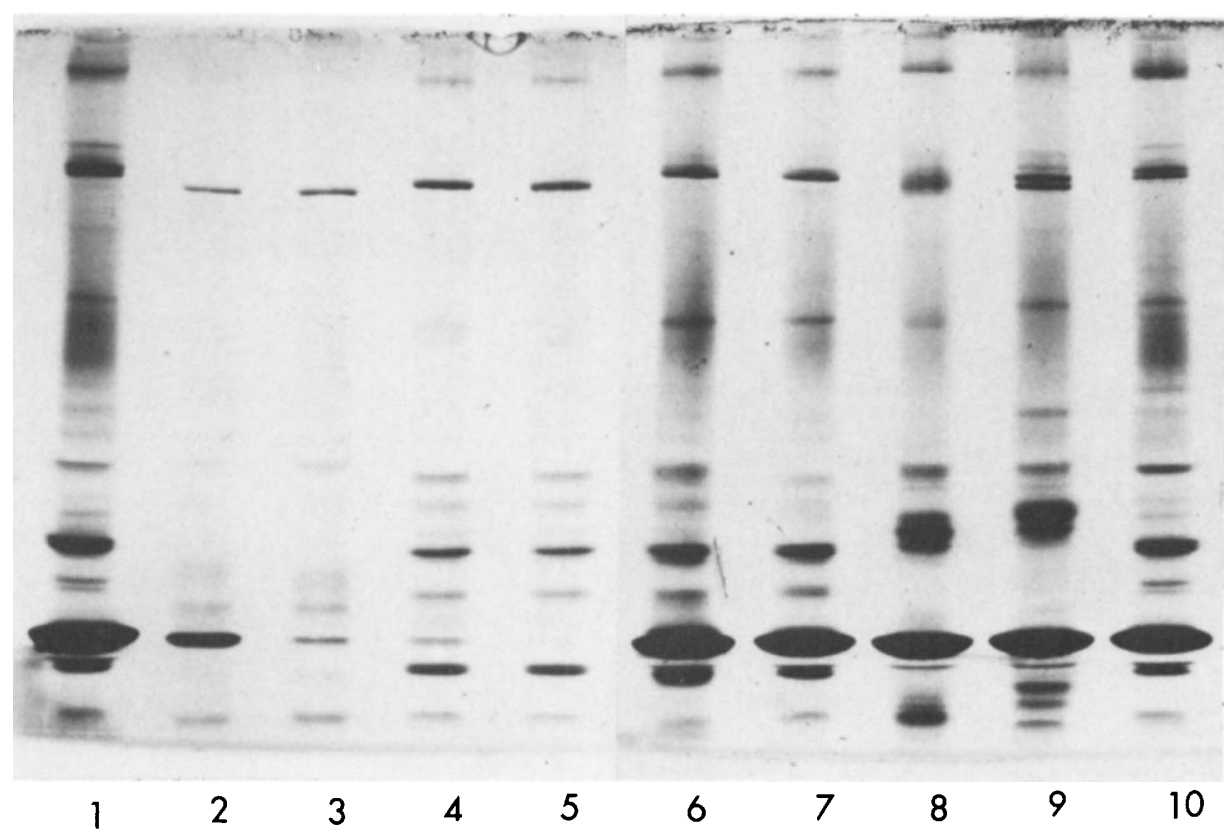

FIG. 1.-Polyacrylamide gradient gel electrophoresis of normal human serum incubated for $24 \mathrm{~h}$ at $37^{\circ} \mathrm{C}$ with cells of $B$. gingivalis (W83, track 2; 381, track 3), B. intermedius (NCTC9336, track 4; UJB13-c, track 5), B. asaccharolyticus (NCTC9337, track 6), B. endodontalis (BN11a-f, track 7), B. loeschei (ATCC15930, track 8), B. melaninogenicus (ATCC25845, track 9) and F. nucleatum (NCTC10562, track 10). Human serum incubated without bacteria was in track 1. 
TABLE

Proteolytic activity and degradation of complement components $C 3$ and $C 5$ and of IgG and IgM in human serum by strains of black-pigmented Bacteroides

\begin{tabular}{|c|c|c|c|c|c|c|}
\hline \multirow[b]{2}{*}{ Strain } & \multirow[b]{2}{*}{ Site of isolation } & \multirow{2}{*}{$\begin{array}{l}\text { Proteo- } \\
\text { lytic } \\
\text { acti- } \\
\text { vity* }\end{array}$} & \multicolumn{4}{|c|}{ Degradation $\dagger$ of } \\
\hline & & & $\mathrm{C} 3$ & C5 & $\mathrm{IgG}$ & $\operatorname{IgM}$ \\
\hline \multicolumn{7}{|c|}{ B. asaccharolyticus } \\
\hline ATCC 25260 & Empyema & - & - & - & - & - \\
\hline ATCC27067 & Leg wound (man) & - & - & - & - & - \\
\hline VPI4199 & Faeces (man) & + & - & - & - & - \\
\hline NCTC9337 & Infected haemorrhoids & + & - & - & - & - \\
\hline B537 & Leg lesion & + & - & - & - & - \\
\hline \multicolumn{7}{|l|}{ B. endodontalis } \\
\hline H11a-e & Infected root canal & + & + & - & ++ & - \\
\hline BN1la-f & Infected root canal & + & + & - & - & - \\
\hline \multicolumn{7}{|l|}{ B. gingivalis } \\
\hline W83 & Clinical specimen & + & +++ & +++ & +++ & +++ \\
\hline W50 & Clinical specimen & + & ++ & +++ & - & ++ \\
\hline 381 & Subgingival plaque & + & +++ & +++ & $++t$ & $++t$ \\
\hline $\mathrm{BE}-\mathrm{c}$ & Infected root canal & + & ++ & +++ & - & ++ \\
\hline TN42-c & Infected root canal & + & +++ & & +++ & + \\
\hline 376 & Periodontitis & + & +++ & +++ & +++ & +++ \\
\hline \multicolumn{7}{|l|}{ B. intermedius } \\
\hline NCTC9336 & Vincent's gingivitis & + & + & - & +++ & ++ \\
\hline$A B 13 a-f$ & Infected root canal & + & + & - & +++ & - \\
\hline $\mathrm{ABg}-\mathrm{c}$ & Infected root canal & + & + & - & ++ & - \\
\hline $\mathrm{BO}-\mathrm{b}$ & Infected root canal & + & + & - & +++ & - \\
\hline PW-c & Infected root canal & + & + & - & ++ & - \\
\hline SL-d & Infected root canal & + & + & - & ++ & - \\
\hline $\mathrm{SN}-\mathrm{c}$ & Infected root canal & + & + & - & - & - \\
\hline SUN-k & Infected root canal & + & + & - & +++ & - \\
\hline UJB13-c & Infected root canal & + & + & - & +++ & - \\
\hline \multicolumn{7}{|l|}{ B. loeschei } \\
\hline ATCC 15930 & Gingival crevice & - & - & - & +++ & - \\
\hline \multicolumn{7}{|c|}{ B. melaninogenicus } \\
\hline ATCC 25845 & Human sputum & - & - & - & - & - \\
\hline VPI9343 & Not known & - & - & - & - & - \\
\hline VPI1 3020 & Periodontitis & - & - & - & - & - \\
\hline
\end{tabular}

*Proteolytic activity was defined as the ability of cells ( $0.3 \mathrm{mg}$ dry weight) in $0.3 \mathrm{ml}$ of MOPS dilution solution and $0.6 \mathrm{ml}$ of human serum to form trichloroacetic acid-soluble material within $24 \mathrm{~h}$.

$\dagger$ Degradation was scored as $+++=$ no detectable amount remaining after $24 \mathrm{~h}$; $++=<25 \% ;+=\geqslant 25 \% \leqslant 75 \% ;-=>75 \%$ detectable after $24 \mathrm{~h}$.

ruminicola ATCC19189, B. thetaiotaomicron NCTC10582, B. ureolyticus VPI7815 and VPI13309, B. vulgatus ATCC8482, C. gingivalis VPI12914, C. ochraceus ATCC27872, $C$. sputigena VPI13178, $F$. gonidiaformans ATCC25563, $F$. naviforme ATCC25832, $F$. necrophorum NCTC10575, F. nucelatum NCTC10562, F. russi ATCC25533, F. varium ATCC8501.

Only black-pigmented Bacteroides strains caused any decrease in the level of 
immunoglobulins or complement components $\mathrm{C} 3$ and $\mathrm{C} 5$ as demonstrated by immunoelectrophoresis and immunodiffusion methods (table). Decreased levels of IgG were found in sera incubated for $24 \mathrm{~h}$ with four of the six strains of $B$. gingivalis and eight of the nine strains of $B$. intermedius. $B$. loeschei strain ATCC15930 and $B$. endodontalis strain H1 la-e also caused a significant decrease of IgG. All strains of $B$. gingivalis tested and $B$. intermedius strain NCTC9336 caused a decrease in the level of IgM. B. gingivalis strains W83, 381 and 376 decomposed both IgM and IgG so efficiently that no traces of these proteins could be detected after $24 \mathrm{~h}$. The amount of C3 was significantly decreased in sera treated with $B$. gingivalis, $B$. intermedius and $B$. endodontalis (table). No traces of $C 3$ could be detected in sera treated with $B$. gingivalis strains W83, 381, 376 and TN42-c (fig 2) while strains W50 and BE-c had less effect on C3 (fig 2). B. intermedius strains and B. endodontalis strains caused a decrease of C3 although not as efficiently as $B$. gingivalis strains (fig 3). $C 5$ could not be detected in sera treated with five of the $B$. gingivalis strains. None of the other species caused any significant decrease in C5 (table I).

The effect of some of the strains on $\mathrm{C} 3$ of serum samples was also evaluated by crossed immunoelectrophoresis. In the presence of $F$. nucleatum strain NCTC10562, C3 was converted into fragments as in serum incubated without bacteria (fig 4). In the

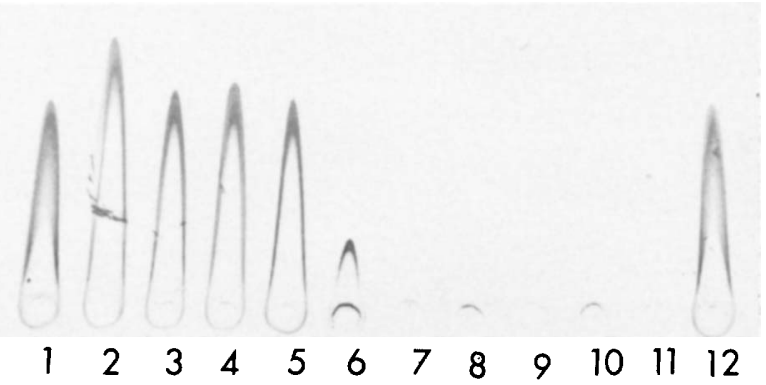

FIG. 2.-C3 assayed by rocket immunoelectrophoresis in serum incubated for $24 \mathrm{~h}$ at $37^{\circ} \mathrm{C}$ with $B$. asaccharolyticus strains ATCC25260, VPI4199, NCTC9337 and B537 (wells 2-5) and B. gingivalis strains W50, BE-c, 376, 381, W83 and TN42-c (Wells 6-11). Unincubated serum was in wells 1 and 12. Before electrophoresis, all sera were diluted with an equal volume of Tris-barbital buffer $(p \mathrm{H} 8 \cdot 6)$ with 5mM EDTA.

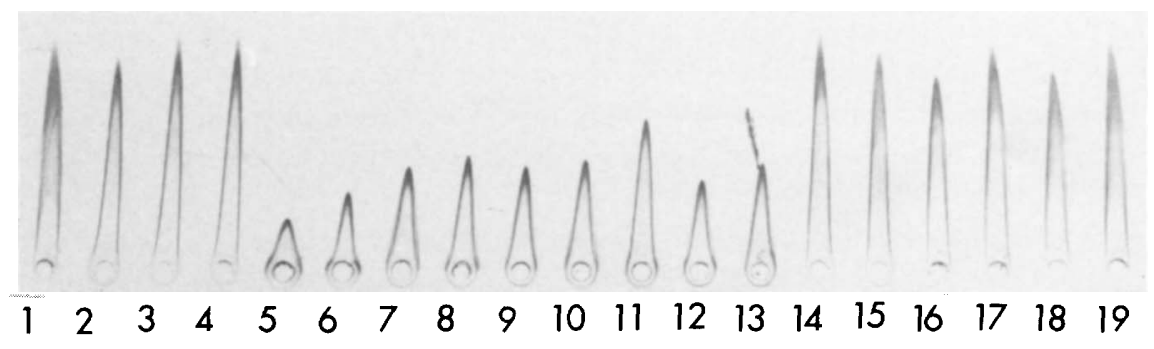

FIG. 3.-C3 assayed by rocket immunoelectrophoresis in serum incubated for $24 \mathrm{~h}$ at $37^{\circ} \mathrm{C}$ with $B$. loeschei ATCC15930 (well 2), B. melaninogenicus ATCC25845 and VPI13020 (wells 3 and 4), B. intermedius NCTC9336, AB13a-f, ABg-c, BO-b, PW-c, SL-d, SN-c and UJB13-c (wells 5-12), B. endodontalis H1la-e (well 13), C. gingivalis VPI12914 (well 14), C. sputigena VPI13178 (well 15), F. gonidiaformans ATCC25563 (well 16), F. nucleatum NCTC10562 (well 17), and F. russi ATCC25533 (well 18). Unincubated serum was in wells 1 and 19 . Before electrophoresis, all sera were diluted with an equal volume of Tris-barbital buffer $(p \mathrm{H} 8.6)$ with 5mM EDTA. 
no bacteria

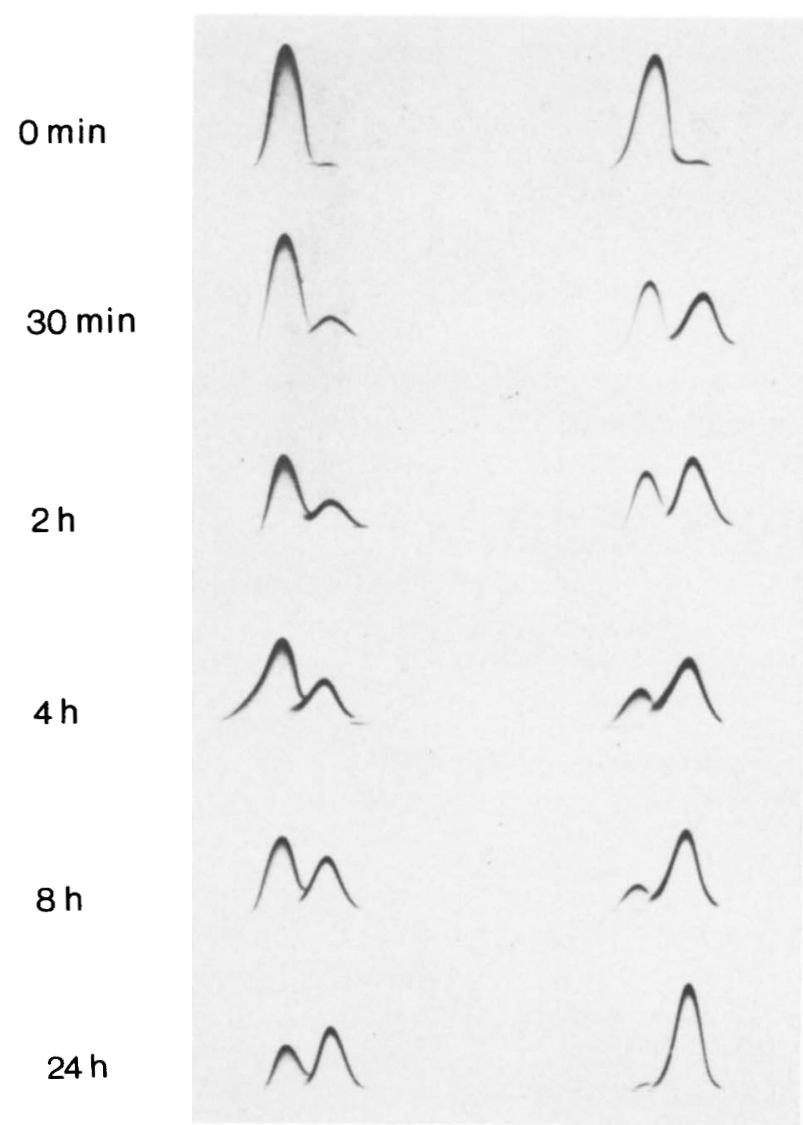

FIG. 4.-Crossed immunoelectrophoresis of normal human serum incubated for $24 \mathrm{~h}$ at $37^{\circ} \mathrm{C}$ without bacteria and with $F$. nucleatum NCTC10562. This $F$. nucleatum strain is representative of strains not causing any decrease in $\mathrm{C} 3$ in rocket immunoelectrophoresis. The cathode is to the left in the first dimension and at the bottom in the second dimension.

presence of $B$. intermedius strain NCTC9336 there was rapid conversion of C3 and the fragments were then further degraded as indicated by changes in their electrophoretic mobilities (fig 5). The most rapid conversion of $\mathrm{C} 3$ was induced by $B$. gingivalis strain W83. The fragments were further degraded and after $8 \mathrm{~h}$ only trace amounts could be detected (fig 6).

By depleting serum of Factor $\mathrm{B}$ and $\mathrm{C} 4$ both the spontaneous conversion of $\mathrm{C} 3$ and that induced by $F$. nucleatum were prevented. $B$. intermedius and $B$. gingivalis also degraded C3 in the depleted serum but at a slower rate and with an electrophoretic pattern different from that induced in normal serum (figs 5 and 6). After incubation for $24 \mathrm{~h}$, no trace of $\mathrm{C} 3$ could be detected by immunoelectrophoresis with antisera against C3, C3c or C3d in serum incubated with $B$. gingivalis strains W83, 381, 376 or TN42-c.

In serum treated for 10 min with $B$. gingivalis strain W83 (fig 7), complement could not be activated by the classical or the alternative pathway. After $30 \mathrm{~min}$, complement 
NHS

NHS without C4

and factor $B$

$2 \mathrm{~h}$

$4 \mathrm{~h}$

$8 \mathrm{~h}$

$24 \mathrm{~h}$
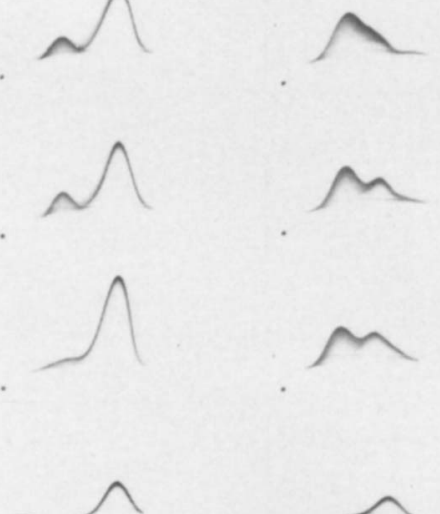

FIG. 5.-Crossed immunoelectrophoresis of normal human serum (NHS) and serum depleted of C4 and Factor B incubated for $24 \mathrm{~h}$ at $37^{\circ} \mathrm{C}$ with B. intermedius NCTC9336. Electrode positions were as in fig. 4.

\section{NHS \\ NHS without C4 \\ and factor $B$}

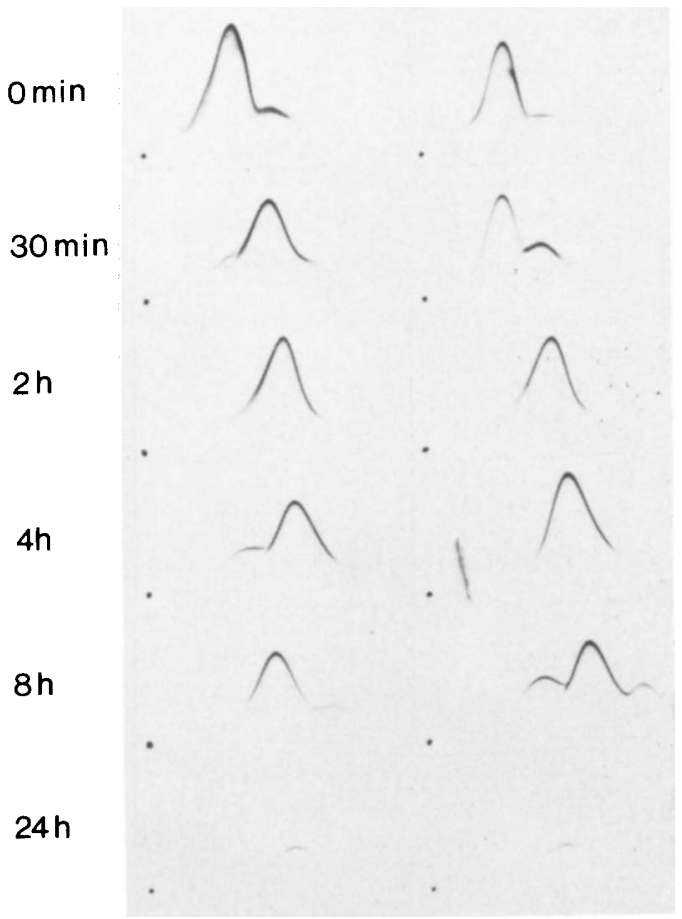

Fig. 6.-Crossed immunoelectrophoresis of normal human serum (NHS) and serum depleted of C4 and Factor B incubated for $24 \mathrm{~h}$ at $37^{\circ} \mathrm{C}$ with B. gingivalis W83. Electrode positions were as in fig. 4 . 

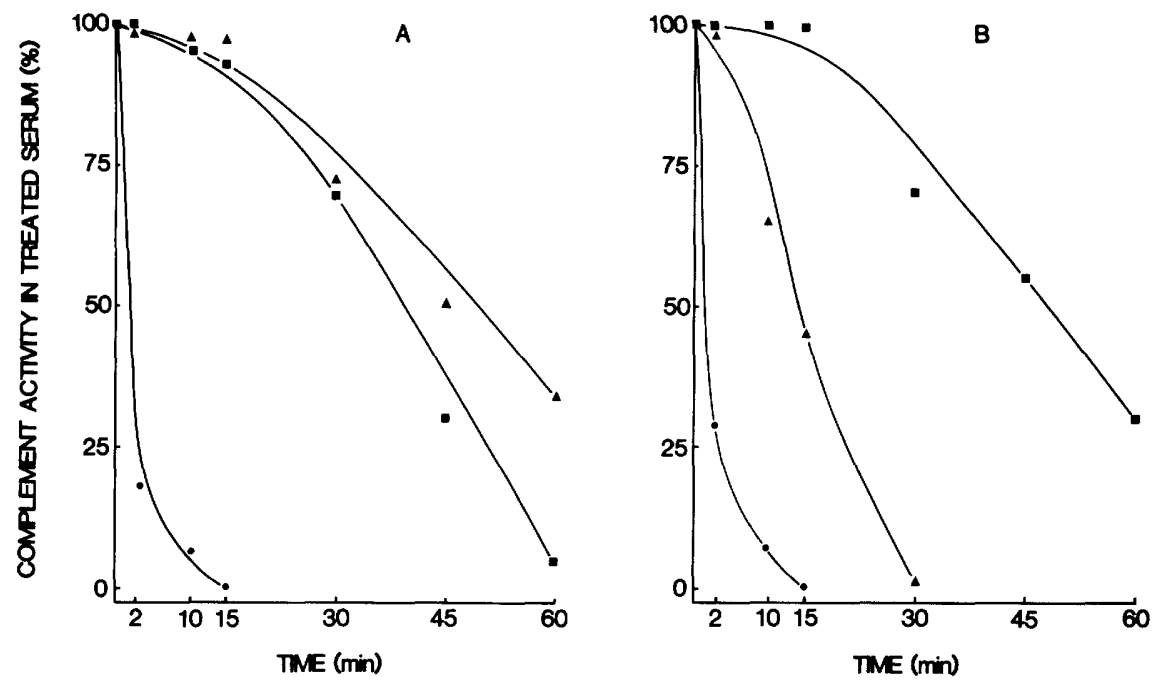

FIG. 7.-Effect of cells of $B$. gingivalis W83 (•), B. intermedius NCTC9336 (4) and $F$. nucleatum NCTC10562 ( $\boldsymbol{D})$ on the complement activity of human serum. Bacteria were incubated in serum, and the percentages of complement activity by the classical (A) and the alternative (B) pathways remaining after various periods of time were recorded as means of six experiments.

in serum treated with $B$. intermedius strain NCTC9336 could not be activated by the alternative way, whereas serum treated with $F$. nucleatum strain WCTC10562 contained complement which could be activated by both pathways even after exposure for $60 \mathrm{~min}$ to the bacterial cells.

\section{Discussion}

Several authors have reported that strains of black-pigmented Bacteroides inhibit the phagocytic killing of other bacteria present in in-vitro systems (Ingham et al., 1977; Tofte et al., 1980; Ingham et al., 1981; Jones and Gemmell, 1982). Also, in experimental polymicrobial infections in guinea pigs, the addition of strains of black-pigmented Bacteroides to an avirulent mixture of bacteria can promote the survival of those bacteria despite the presence of large numbers polymorphonuclear leukocytes (MacDonald, Socransky and Gibbons, 1963; Socransky and Gibbons, 1965; Sundqvist et al., 1979; Mayrand et al., 1980). It is not known how the bacteria evade the antimicrobial action of the leukocytes. However, the results reported here suggest that some Bacteroides strains may degrade immunoglobulins and components of complement, known to be important in the phagocytosis and subsequent killing of bacteria by polymorphonuclear leukocytes. We have previously reported that the tissue fluid of sites in guinea pigs infected with $B$. gingivalis strain W83 contained no C3 and only traces of immunoglobulins (Sundqvist et al.,1984).

Our findings that IgG and IgM are degraded by $B$. gingivalis and $B$. intermedius are in accord with previous results indicating that black-pigmented Bacteroides have such activity (Werner and Müller, 1971; Kilian, 1981; Sundqvist et al., 1984). We could not, however, confirm that $B$. asaccharolyticus degrades these immunoglobulins (Werner and Müller, 1971; Kilian, 1981). 
It is probable that most of the strains used in this study activated complement by physiological pathways. However, B. gingivalis, B. intermedius and B. endodontalis also caused a degradation of $\mathrm{C} 3$ fragments. Most of the $B$. gingivalis strains degraded $\mathrm{C} 3$ as well as $\mathrm{C} 5$ until fragments could no longer be detected with anti-C3, anti-C3c, anti $\mathrm{C} 3 \mathrm{~d}$ or anti-C5 sera. This degradation was probably independent of complement activation because $\mathrm{C} 3$ was degraded in human serum in which the classical and alternative pathways of complement activation were blocked by depletion of $\mathrm{C} 4$ and Factor B.

Complement components $\mathrm{C} 3$ and $\mathrm{C} 5$ of human serum have previously been demonstrated to be cleaved into biologically active fragments by proteinases from $S$. marcescens and a $\beta$-haemolytic streptococcus (Ward et al., 1973). An elastase from $P$. aeruginosa has been shown to destroy the complement-dependent haemolytic activity of serum and the phagocytic activity of leukocytes (Schultz and Miller, 1974). B. gingivalis enzymes degrade not only C3, C5 and immunoglobulins of human serum but also albumin, haptoglobulin, haemopexin, transferrin and the proteinase inhibitors $\alpha$-1-antitrypsin and $\alpha$-2-macroglobulin (Carlsson, Höfling and Sundqvist, 1984; Carlsson et al., 1984). These characteristics may explain the high pathogenic potential of B. gingivalis (McDonald et al., 1963; Mayrand et al., 1980; van Steenbergen et al., 1982; Sundqvist et al., 1984). By degrading complement and immunoglobulin, $B$. gingivalis may evade the phagocytic host defence. The capacity to degrade the plasma proteinase inhibitors may remove those plasma proteins aimed at protecting the tissue against proteinases released by phagocytes and bacterial cells. Also, by degrading the haem-binding plasma proteins haemopexin and albumin, B. gingivalis may support the growth of haem-requiring organisms at infected sites.

This study was supported by the Swedish Medical Research Council (project nos 6270 and 4977).

\section{REFERENCES}

Carlsson J, Herrmann B F, Höfling J F, Sundqvist G K 1984 Degradation of the human proteinase inhibitors alpha-1-antitrypsin and alpha-2-macroglobulin by Bacteroides gingivalis. Infection and Immunity 43:644-648.

Carlsson J, Höfling J F, Sundqvist G K 1984 Degradation of albumin, haemopexin, haptoglobin and transferrin by black-pigmented Bacteroides species. Journal of Medical Microbiology $18: 39-46$

Fong J S C, Renaud L 1978 A hemolytic plate method for alternate-pathway complement activity assay. American Journal of Clinical Pathology 69:156-160.

Ganrot P O 1972 Crossed immunoelectrophoresis. Scandinavian Journal of Clinical Laboratory Investigation Suppl 124:39-47.

Holdeman L V, Cato E P, Moore W E C 1977 Anaerobe laboratory manual, 4th edn. Virginia Polytechnic Institute and State University, Blacksburg VA, pp 144-148.

Ingham H R, Sisson P R, Middleton R L, Narang H K, Codd A A, Selkon J B 1981 Phagocytosis and killing of bacteria in aerobic and anaerobic conditions. Journal of Medical Microbiology 14:391-399.

Ingham H R, Sisson P R, Tharagonnet D, Selkon J B, Codd A A 1977 Inhibition of phagocytosis in vitro by obligate anaerobes. Lancet 2:1252:1254.

Jones G R, Gemmell C G 1982 Impairment by Bacteroides species of opsonisation and phagocytosis of enterobacteria. Journal of Medical Microbiology 15:351-361.

Kilian M 1981 Degradation of immunoglobulins A1, A2, and $G$ by suspected principal periodontal pathogens. Infection and Immunity 34:757-765.

Kilian M, Mestecky J, Schrohenloher R E 1979 Pathogenic species of the genus Haemophilus 
and Streptococcus pneumoniae produce immunoglobulin Al protease. Infection and Immunity 26:143-149.

Lange K 1962 Über den immunologischen Mechanismus der akuten und der chronischen Glomerulonephritis. In: Wollheim E (ed) Glomeruläre und tubuläre Nierenerkrankungen. Georg Thieme Verlag, Stuttgart, pp 232-245.

Laurell C-B 1972 Electroimmuno assay. Scandinavian Journal of Clinical Laboratory Investigation Suppl 124:21-37.

Löfgren S, Tärnvik A, Carlsson J 1980 Demonstration of opsonizing antibodies to Francisella tularensis by leukocyte chemiluminescence. Infection and Immunity 29:329-334.

MacDonald J B, Socransky S S, Gibbons R J 1963 Aspects of the pathogenesis of mixed anaerobic infections of mucous membranes. Journal of Dental Research 42 (Suppl): $529-544$.

Male C J 1979 Immunoglobulin A1 protease production by Haemophilus influenzae and Streptococcus pneumoniae. Infection and Immunity 26:254-261.

Mayrand D, McBride B C, Edwards T, Jensen S 1980 Characterization of Bacteroides asaccharolyticus and B. melaninogenicus oral isolates. Canadian Journal of Microbiology 26:1178:1183.

Neidhardt F C, Bloch P L, Smith D F 1974 Culture medium for enterobacteria. Journal of Bacteriology 119:736:747.

Plaut A G, Gilbert J V, Artenstein M S, Capra J D 1975 Neisseria gonorrhoeae and Neisseria meningitidis: extracellular enzyme cleaves human immunoglobulin A. Science 190:1103-1105.

Schultz D R, Miller K D 1974 Elastase of Pseudomonas aeruginosa: Inactivation of complement components and complement-derived chemotactic and phagocytic factors. Infection and Immunity 10:128-135.

Socransky S S, Gibbons R J 1965 Required role of Bacteroides melaninogenicus in mixed anaerobic infections. Journal of Infectious Disease 115:247-253.

Sundqvist G K, Eckerbom M I, Larsson Å P, Sjögren U T 1979 Capacity of anaerobic bacteria from necrotic dental pulps to induce purulent infections. Infection and Immunity 25:685-693.

Sundqvist G K, Carlsson J, Herrmann B F, Höfling J F, Väätäinen A 1984 Degradation in vivo of the $\mathrm{C} 3$ protein of guinea-pig complement by a pathogenic strain of Bacteroides gingivalis. Scandinavian Journal of Dental Research 92:14-24.

Tofte R W, Peterson P K, Schmeling D, Bracke J, Kim Y, Quie P G 1980 Opsonization of four Bacteroides species: role of the classical complement pathway and immunoglobulin. Infection and Immunity 27:784-792.

van Steenbergen T J M, Kastelein P, Touw J J A, De Graaff J 1982 Virulence of black-pigmented Bacteroides strains from periodontal pockets and other sites in experimentally induced skin lesions in mice. Journal of Periodontal Research 17:41-49.

Ward P A, Chapitis J, Conroy M C, Lepow I H 1973 Generation by bacterial proteinases of leukotactic factors from human serum, and human C3 and C5. The Journal of Immunology 110:1003-1009.

Werner H, Müller H E 1971 Immunelektrophoretische Untersuchungen über die Einwirkung von Bacteroides-, Fusobacterium-, Leptotrichia- und Spaerophorus-Arten auf menschliche Plasmaproteine. Zentralblatt für Bakteriologie I Abt. Orig. 216:96-113. 